\title{
A study on agricultural credit in adoption of technology in banana cultivating farms in Tamil $\mathrm{Nadu}$
}

See end of the paper for authors' affiliations

Correspondence to :

\section{S. Padma Rani}

Department of Agricultural Economics, Tamil Nadu Agricultural

University, Coimbatore (T.N.) India

Email : padmaranisenthil

@yahoo.com

Paper History :

Received : 22.04.2019;

Revised : 03.07.2019;

Accepted : 05.08.2019
ABSTRACT : Agriculture as a primary sector continues to play a dominant role in increasing the growth and development of Indian economy and it is important to revitalize the agricultural sector, for which agricultural investment flow is necessitated in the agriculture sector. In order to increase the investment flow to agriculture sector, institutional credit has contributed greatly right from the 'Green Revolution Period'. Agricultural credit helps farmers to go for short-term credit for purchase of high cost inputs and other services and for making investment on capital assets with the support of long term credit facility. Further, for adoption of new technological inputs and enhancing farm productivity farm finance becomes inevitable. Probit model was used to find out the impact of credit on technology adoption. The probit analysis was done between short term borrowers, growing tissue culture (technology adopter) and conventional varieties of growing banana (technology non adopter). Independent variables included in the model were: age, education, experience, amount of credit borrowed, family size, number of extension contacts, farm size ,total farm income and distance to formal and informal financial institution probit model was used for evaluating the factors determining adoption of tissue culture banana- a new technology in banana cultivation among sample respondents. The co-efficient of credit amount borrowed was 0.05 which implied that increase in credit amount by one unit would increase 5 per cent in the probability of adoption of tissue culture technology. The marginal effect of credit amount borrowed was 0.36 which showed that an unit increase in the amount borrowed would result in 36 per cent increase in technology adoption. And also the study found out that Increase in farm income and extension agency contact have positive effect on technology adoption.

KEY WORDS : Agricultural credit, Technology adoption, Marginal effect

How To Cite This PAper : Rani, S. Padma, Mani, K. and Vidhyavathi, A. (2019). A study on agricultural credit in adoption of technology in banana cultivating farms in Tamil Nadu. Internat. Res. J. Agric. Eco. \& Stat., 10 (2) : 194-200, DOI : 10.15740/HAS/IRJAES/10.2/194-200. Copyright@ 2019: Hind Agri-Horticultural Society. 